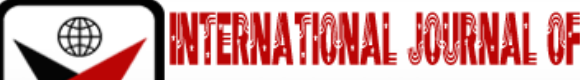

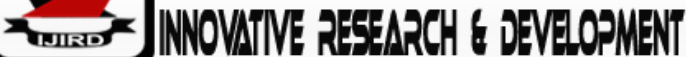

ISSN 2278-0211 (Online)

\section{Effect of Experiential Teaching Strategy on Senior Secondary School Students' Retention and Self-efficacy in Physics in Ondo, Nigeria}

\author{
Dr. Bada, Abiodun Adekunle \\ Lecturer, Department of Curriculum and Instruction, \\ Adeyemi College of Education, Ondo, Nigeria \\ Dr. Akinbobola, Akinyemi Olufunminiyi \\ Lecturer, Department of Curriculum and Instruction, \\ Adeyemi College of Education, Ondo, Nigeria
}

\begin{abstract}
:
The performance of senior school students in external physics examinations is still not one hundred percent due to many factors which include: poor attitude, poor motivation, poorly sourced teaching and learning environment and poor teaching methods. Several other innovative teaching methods such as experiential teaching strategy (ETS) have been used in other parts of the world, which have improved the teaching and learning of physics. This study investigated the (i) effects of experiential teaching strategy (ETS) on students' retention in physics in Ondo (ii) influence of students' self-efficacy when taught physics using experiential teaching strategy. The study was a quasi-experimental, non-randomised, non-equivalent, pretest and posttest control group design. Two intact classes of senior school II physics students from two senior secondary schools took part in the study. A total of 95 students comprising of two groups, experimental group (EG = 42) and control group (CG = 53) were involved. The instruments were Physics Performance Test (PPT) and Physics Students Self-Efficacy Questionnaire (PSSEQ). The reliability of PPT and PSSEQ was done using Kuder-Richardson' Formular 21 ( $r=0.77)$ and Cronbach Alpha Coefficient $(r=0.97)$ respectively. Two research questions were answered and two hypotheses were tested using t-test and Analysis of Covariance. Findings from the study revealed that: (i) physics students taught physics using experiential teaching strategy were able to retain physics concepts learnt better than students taught physics using conventional teaching strategy (ii) there was no significant difference among high, medium and low students' self-efficacy when taught physics using experiential teaching strategy. The study concluded that students who were taught physics using ETS out-performed students in the control group. The implication of this study is that students' performance in physics would be better if students are taught using experiential teaching strategy.
\end{abstract}

Keywords: Experiential teaching strategy, Retention, Self-Efficacy

\section{Introduction}

Physics is one of the fundamental science subjects required for the improvement of any country. It is a part of physical science that manages the properties and nature of energy, matter and heat, mechanics, light, sound, electricity, magnetism, the structures of molecules and other radiation. Omosewo (2009) defined physics as an aspect of science that focuses on energy and matter and their interactions.

Physics education is a fulcrum among the sciences that requires unique consideration as a result of its abstract nature. Headway in Information and Communication Technology (ICT), medicine, environment, wrongdoing control and security are accomplishments conveyed to fore through the learning of physics. The results of physics, for example, the improvement of present-day home devices (Television, clothes washer, electric stove, cooler and so on) have made life less demanding for man to have an important and cheerful living in the society.

In spite of the vital possibilities implanted in studying physics, its significance to humanity and the efforts of specialists to enhance the nature of its teaching and learning particularly at the senior secondary school level, there is still opportunity to get better in the enrolment and academic performance of students in the subject. Table 1 outlines the enrolment and performance of students in the West African Examinations Council (WAEC) in the last five years. Table 1 shows that despite the relatively good performance of students in physics $(78.49 \%)$ which was recorded in the year 2018, researchers especially physics educators are still concerned about the $21.51 \%$ of students who had below last credit in their examination.

If Nigeria is to accomplish her set objectives of scientific and technological improvement, the need for students to perform magnificently well in science-based subjects with exceptional thoughtfulness regarding physics cannot be over- 
stressed. Despite the efforts of governments and concerned science teachers in training and re-training of teachers and in the acquisition of science materials and equipment, students' enrolment and academic performance still falls below the desires of physics teachers particularly in their performance in the West African Senior School Certificate Examinations.

Omosewo (2009) examined the need to prepare and retrain physics teachers in Nigeria and found out that numerous teachers handling science subjects in the senior secondary schools have experience in science and not science education. This made Aina and Keith (2015) to opine that these science teachers needed adequate instructional techniques for teaching but regularly utilize lecture method. Physics education researchers have recognized that the customary lecture method known as conventional method for teaching physics failed to give profound situated theoretical and practical comprehension of physics contents in students (Clark \& Elen, 2006). It is yet to be given full thought that issues, for example, the utilization of innovative teaching techniques like experiential teaching strategy could enhance retention and influence physics students' self-efficacy

\begin{tabular}{|c|c|c|c|c|c|}
\hline Year & $\begin{array}{c}\text { Total Numbers } \\
\text { of Students Who } \\
\text { Entered }\end{array}$ & $\begin{array}{c}\text { Total Credit } \\
\text { Passed (A1-C6) }\end{array}$ & $\begin{array}{c}\text { \% Credit Passed } \\
\text { (A1-C6) }\end{array}$ & $\begin{array}{c}\text { Total Failed } \\
\text { (D7-F9) }\end{array}$ & $\begin{array}{c}\text { \% Failed } \\
\text { (D7-F9) }\end{array}$ \\
\hline 2015 & 684124 & 410543 & 60.01 & 273581 & 39.99 \\
\hline 2016 & 705125 & 415655 & 58.95 & 289470 & 41.05 \\
\hline 2017 & 377851 & 205757 & 54.45 & 172094 & 45.55 \\
\hline 2018 & 728354 & 571687 & 78.49 & 156667 & 21.51 \\
\hline 2019 & 725853 & 565746 & 77.94 & 160107 & 22.06 \\
\hline
\end{tabular}

Table 1: Candidates' Enrolment and Performance in May/June West African

Examinations in Physics in Nigeria: 2015-2019

Source: Statistics Section WAEC Office Yaba Lagos 2019

Achenbach and Arthur (2002) conducted a research on the impact of experiential learning on students' existing cultural schemas. Their finding includes the recommendation of experiential learning as a method that could bridge theory and practice and the development of competencies in learners.

Experiential teaching accentuates the part of hands-on, individual involvement in building information. Experiential teaching strategies are very valuable for competency improvement since they furnish students with a chance to hone their abilities and think about the experience. Hence, experiential teaching methods are appropriate for working with teachers as teaching requires computerizing teaching competencies, or the ability to participate in honed practices with negligible intellectual handling.

Researchers such has Jensen (2000), Achenbach and Arthur (2002), Christy (2007), Demirbas and Demirkan (2007), Powell and Wells (2010), Pfeifer and Borozon (2011), Wambugu, Changeiywo and Ndiritu (2014), Noor (2015), Dongmei (2016), Bada and Akinbobola (2017), and Ilhami (2018) have researched into the effectiveness of experiential teaching strategy and found it useful.

The concept of self-efficacy grew out of conviction that cognitive stage plays a crucial role in the learning of new behaviours (Bandura, 1997). It is the central component of Bandura's Social Cognitive Theory. As such, self-efficacy plays an important role in the cognitive appraisal of person, environment, and behavioural variables. It is also key to determine a person's choice of behaviour, effort and strong wiliness in the face of problems, and state of physiological arousal. Researchers such as Bandura (1997), Adeyemo and Agokei (2009) has worked on the effects of self-efficacy on different subjects. They found out that self-efficacy may mediate performance but might not be the only mediating concept.

\subsection{Statement of the Problem}

The performance of senior secondary school students in physics has not been excellent in the last five years. Studies completed by researchers have accredited this circumstance to a few variables, such as, poor perception, poor motivation, inadequately sourced learning and teaching condition and poor teaching strategies (Harry, 2011 and Erinosho, 2013). Scholars such as Wambugu, Changeiywo and Ndiritu, (2014); Nweke, Abonyi, Omebe and Njoku, (2014) have worked on the effects of experiential teaching strategy on students' performance in physics. Their works have focused for the most part on students' motivation and achievement when experiential teaching strategy was utilized.

Finding from the reviewed literature revealed that little or no study has been carried out on the effects of experiential teaching strategy in Ondo, Nigeria. Despite all the researches that have been carried out through the use of carefully planned instructional strategies and models to better the status of physics teaching and learning, all these strategies gave little improvement over the conventional expository method, which is been used in the secondary schools. This study filled up the existing gap as it determined the effects of experiential teaching strategy on students' retention in physics with reference to students' self-efficacy towards physics.

\subsection{Purpose of the Study}

The study investigated the:

- Effects of experiential teaching strategy on student's retention in physics?

- Difference in the performance of high, medium and low self-efficacy students taught physics using experiential teaching strategy 


\subsection{Research Questions}

The following research questions were raised and answered in this study:

- What is the effect of experiential teaching strategy on student's retention in physics after two weeks?

- What is the difference in the performance of high, medium and low self-efficacy students taught physics using experiential teaching strategy?

\subsection{Research Hypotheses}

- $\mathrm{HO}_{1:}$ There is no significant effect of experiential teaching strategy on students' retention in physics.

- $\mathrm{HO}_{2}$ : There is no significant difference in the performance of high, medium and low self-efficacy students' when taught physics using experiential teaching strategy.

\section{Method}

The study adopted pretest, posttest control group design. Simple random sampling technique was adopted to select two schools used for the study in Ondo West Local Government Area of Ondo State, Nigeria. The sample used for the study were ninety-five (95) senior secondary two (SS 2) Physics students. The study made use of Physics Performance Test (PPT) with internal consistency of 0.77 using Kuder-Richardson formular 21 and Physics Students Self-Efficacy Questionnaire (PSSEQ) with internal consistency using Cronbach Alpha Coefficient ( $r=0.97$ ). One intact class was randomly selected from each school used for the study. Experimental group was taught the concept of optics with experiential teaching strategy while the control group was taught the concept of optics using conventional teaching strategy.

The teaching for experimental and control groups lasted for three weeks. Retention test took place three weeks after the posttest without informing the students. The pretest, posttest and retention test contained the same questions except that it was reshuffled before administration in each case. The data collected were analysed using descriptive and inferential statistics.

\section{Results}

- Research Question 1: What is the effect of experiential teaching strategy on students' retention in physics?

Table 2 shows the effect of experiential teaching strategy on students' retention in physics after two weeks. The mean gain score of students taught physics using experiential teaching strategy was 33.42 while the mean gain score of students in the control group was 25.39. The mean gain score of those taught physics using experiential teaching strategy was 8.03 higher than that of the control group.

Figure 1 shows the retention scores of the experimental group and the control group. The bar heights of the pretest mean score of the two groups are almost the same, hence, it implies that the two groups were almost equivalent before treatment. The bar height of the retention mean scores of the experimental group was higher than the control group. Therefore, there was a difference in the retention of the experimental group and the control group in favour of the experimental group after treatment.

\begin{tabular}{|c|c|c|c|c|c|}
\hline Group & $\begin{array}{c}\text { Group } \\
\text { Statistic }\end{array}$ & Pretest & Retention & Mean Gain Score & Difference \\
\hline Experiential & $\mathrm{N}$ & 42 & 42 & & \\
\hline & Mean & 25.67 & 59.09 & 33.42 & 8.03 \\
\hline & SD & 7.999 & 8.62 & & \\
\hline Control & N & 53 & 53 & & \\
\hline & Mean & 24.42 & 49.81 & & \\
\hline
\end{tabular}

Table 2: Students' Performance in Retention Test for both Experimental Group and Control Group

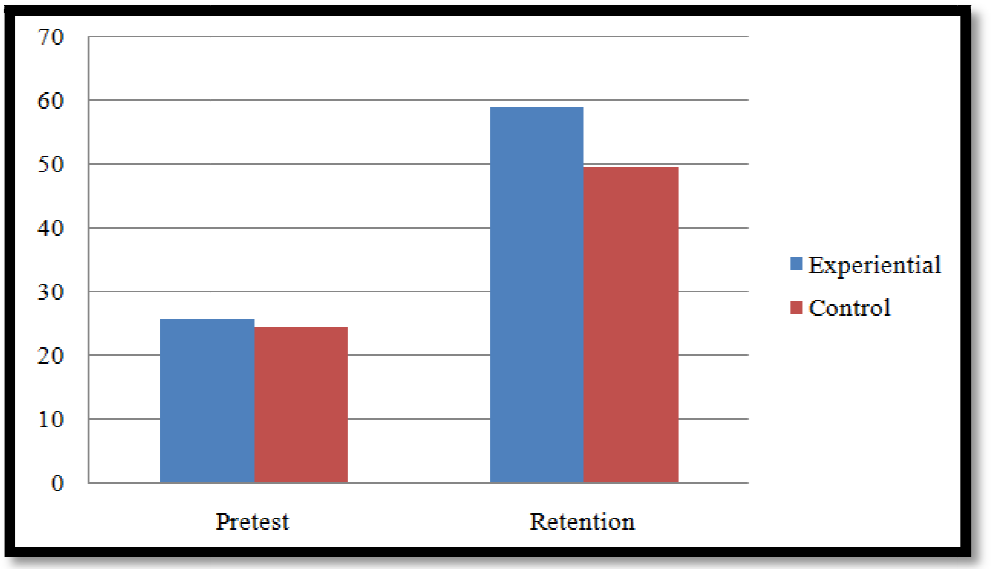

Figure 1: Bar Chart of the Retention of Students Taught Physics Using Experiential Teaching Strategy and Control Group 
- $\quad \mathrm{HO}_{1}$ : There is no significant effect of experiential teaching strategy on students' retention in physics.

From Table 3, the calculated t-value was 5.05 while the degree of freedom computed at 0.05 level of significance is 93. Since the calculated level of significance of 0.00 is less than the table value of 0.05 , the hypothesis is rejected. This implies that there is a significant difference in the retention of students taught physics using experiential teaching strategy and the retention of their counterparts taught physics using conventional teaching strategy (CG), t-93 $=5.05, p<0.05$. Thus, treatment has significant effect on students' physics retention test when taught using experiential teaching strategy.

\begin{tabular}{|c|c|c|c|c|c|c|c|}
\hline Groups & $\mathbf{N}$ & Mean & Std. & Df & t & Sig. & Remark \\
\hline EG2 & 42 & 59.09 & 1.84 & & & & \\
\hline CG & & & & 93 & 5.05 & .00 & ${ }^{*}$ S \\
\hline
\end{tabular}

Table 3: t-test Analysis of the Effect of Experiential Teaching Strategy on Students' Retention Test in Physics

$$
P<0.05
$$

- $\quad$ Research Question 2: What is the difference in the performance of high, medium and low self-efficacy students taught physics using experiential teaching strategy?

Table 4 shows the performance of high, medium and low self-efficacy students' taught Physics using experiential teaching strategy. The mean gain score of the low, medium and high self-efficacy students were 32.29, 31.47 and 33.00 respectively. The high scoring students had the highest mean gain score followed by the low scoring students while the medium scoring students had the least mean gain score.

Figure 2 shows the bar chart of the performance of low, medium and high self-efficacy students taught physics using experiential teaching strategy. The bar height of the pretest mean scores of the three groups are almost equal, hence, it implies that the three groups were almost equivalent before treatment. The bar heights of the posttest mean scores of the three groups were almost equal. This implies that there was no difference in the performance of students taught physics using experiential teaching strategy based on students' self-efficacy to Physics.

\begin{tabular}{|c|c|c|c|c|}
\hline Group & Group Statistic & Pre-test & Post-test & Mean Gain Score \\
\hline Low & $\mathrm{N}$ & 21 & 21 & \\
\hline & Mean & 26.19 & 58.48 & 32.29 \\
\hline & SD & 7.67 & 9.55 & \\
\hline Medium & $\mathrm{N}$ & 15 & 15 & 31.47 \\
\hline & Mean & 25.73 & 57.20 & \\
\hline High & SD & 9.94 & 10.41 & 33.00 \\
\hline & N & 6 & 6 & \\
\hline & Mean & 23.67 & 56.67 & 3.93 \\
\hline
\end{tabular}

Table 4: Performance of Low, Medium and High Self-Efficacy Students' Taught Physics Using Experiential Teaching Strategy

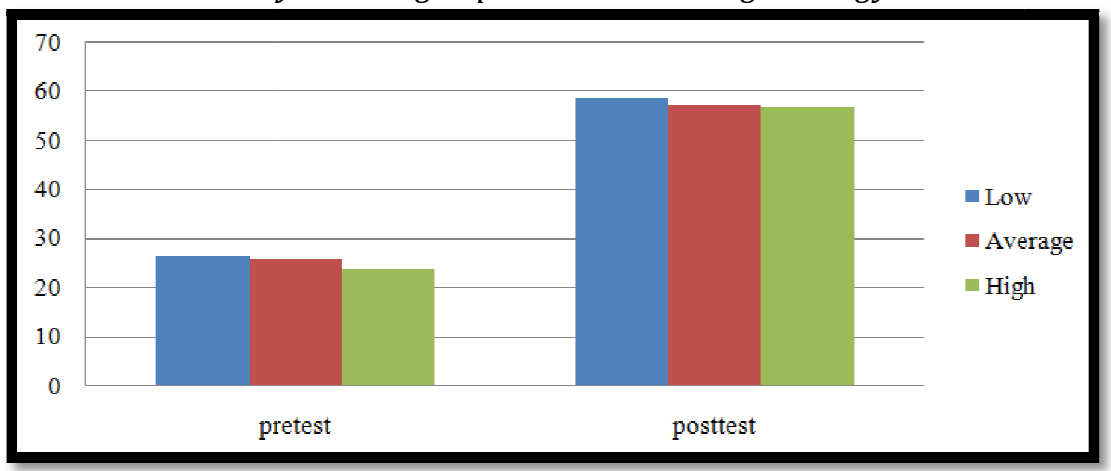

Figure 2: Bar Chart of the Performance of Low, Medium and High Self-Efficacy Students Taught Physics Using Experiential Teaching Strategy

- $\quad \mathrm{HO}_{2}$ : There is no significant difference in the performance of high, medium and low self-efficacy students' when taught physics using experiential teaching strategy.

The analysis in Table 5, revealed the performance of students after treatment over a period of seven weeks when experiential teaching strategy was used to teach students. In the case of performance after treatment, the calculated Fvalue is 0.46 while the degree of freedom is 2 , computed at a level of significance of 0.05 . Since the calculated level of significance of 0.63 is greater than 0.05 , it means there is no significant difference in the performance of low, medium and high scoring students taught Physics using experiential teaching strategy based on self-efficacy, $F_{(2,41)}=0.46 ; p>0.05$. Based on that, the researcher accepts the null hypothesis two. 


\begin{tabular}{|c|c|c|c|c|c|}
\hline Source & $\begin{array}{c}\text { Type III Sum of } \\
\text { Squares }\end{array}$ & Df & Mean Square & F & sig. \\
\hline Corrected Model & $2917.901^{\mathrm{a}}$ & 3 & 972.634 & 70.572 & .00 \\
\hline Intercept & 3442.591 & 1 & 3442.591 & 249.788 & .00 \\
\hline Pre-test & 2895.253 & 1 & 2895.253 & 210.074 & .00 \\
\hline ETS & 12.711 & 2 & 6.356 & .46 & .63 \\
\hline Error & 523.718 & 38 & 13.78 & & \\
\hline Total & 143572.000 & 42 & & & \\
\hline Corrected Total & 4819.478 & 41 & & & \\
\hline
\end{tabular}

Table 5: Analysis of the Performance of High, Medium and Low Students' Self-Efficacy

When Taught Using Experiential Teaching Strategy

a. $R$ Squared $=.848$ (Adjusted $R$ Squared $=.836$ )

\section{Discussion}

The study investigated the effects of experiential teaching strategy on senior school students' performance in physics in Ondo, Nigeria. Two research groups were involved in the study. Experimental group was taught physics using experiential teaching strategy and the control group was taught physics using conventional teaching strategy. The finding revealed that there was a significant difference in the retention scores of students' taught physics using experiential teaching strategy and those taught physics using conventional teaching strategy in favour of the experimental group. This finding agreed with that of Achenbach and Arthur (2002), Wambugu, Changeiywo and Ndiritu (2014), and Ilhami (2018) who found a significant effect of experiential teaching strategy on students' retention and performance.

The finding on students' self-efficacy to physics showed that there was no significant difference in the performance of high, medium and low self-efficacy physics students. This finding is in agreement with Adeyemo and Agokei (2009) who stated that self-efficacy mediates the relationship between knowledge and action however, it is not the only determinant of behavior.

\section{Conclusion}

The study investigated the effects of experiential teaching strategy on senior school students' retention ad selfefficacy to Physics. The finding of this study also indicated that students' who were taught physics using experiential teaching strategy were able to retain content learnt better and longer than those in the control group.

The finding of this study showed that students' self-efficacy towards physics did not have any influence on students' performance in physics when taught using experiential teaching strategy. It could be concluded that the three self-efficacy groups (low, medium, high) benefitted equally from this study.

\section{Recommendations}

Based on the findings of this study, the following recommendations were considered appropriate to enhance the teaching and learning of physics:

- Experiential teaching strategy should be used to teach physics at the senior secondary school.

- The professional bodies like National Teacher Institute (NTI), Nigerian Institute of Physics (NIP), Science Teachers Association of Nigeria (STAN) and Teachers Registration Council of Nigeria (TRCN) should organize seminars and workshops for teachers on how to use experiential teaching strategy for effective teaching and learning process.

- The Ministries of Education at both State and Federal levels should organize workshops for in-service teachers of physics on the effective use of experiential teaching strategy.

\section{References}

i. Achenbach, K., \& Arthur, N. (2002). Experiential learning: Bridging theory to practice in multicultural counseling. Guidance and Counseling Journal, 17(2), 39 - 47

ii. Adeyemo, D. A., \& Agokei, R. C. (2009). The effects of circadian typology, emotional intelligence and creativity on the academic self-efficacy of secondary school students in Delta State, Nigeria. African Journal of Educational Research, 13(1/2), 203-213

iii. Aina, J. K., \& Keith, L. (2015). Teaching method in science education: The need for a paradigmshift to peer instruction (PI) in Nigeria schools. International Journal of Academic Research and Reflection, 3(6), 6-15. Retrieved from http://www.idpublications.org

iv. Bada, A. A., \& Akinbobola, A. O. (2017) Effectiveness of experiential teaching strategy on students' achievement and scoring levels in senior secondary school physics. European Journal of Educational Studies, 3(12), $552-564$

v. Bandura, A. (1997). Self-Efficacy: The Exercise of Control. New York: W.H. Freeman and Company.

vi. Christy, T. (2007). Impact of experiential learning theory on Latino college students' identity, relationships and connectedness to community. Journal of Hispanic Higher Education, 6(1), 52 -72

vii. Clark, R. E., \& Elen, J. (2006). When less is more. Research and theory insights about instruction for complex learning. In R. E. Clark \& J. Elens (Eds.). Handling complexity in learning environment: Research and Theory, 283295). London: Elbevier 
viii. Demirbas, O., \& Demirkan, H. (2007). Learning styles of design students and the relationship of academic performance and gender in design education. Learning and Instruction, 17(3), 345 - 359

ix. Dongmei, S. (2016). A case study of experiential teaching methods in EFL listening. 6th International Conference on Electric, Mechanical, Information and Management, 1475 - 1478

X. Erinosho, S. Y. (2013). How do students perceive the dificulty of physics in secondary schools: An exploratory study in Nigeria. International Journal for Cross-Disciplinary Subjects in Education, 3(3), 1510-1515.

xi. Harry, I. H. (2011). Attitude of students towards science and science education (A case study ofselected secondary schools in river state). Continental Journal of Educational Research, 4(2), 33-51. Retrieved from http://www.krepublishers.com

xii. Ilhami, A. (2018). The use of qualitative case studies as an experiential teaching method in thetraining of preservice teachers. International Journal of Higher Education, 7(1), 112-125

xiii. Noor, S. A. (2015). The effect of experiential learning on improving the performance of EFL students as perceived by teachers of English in the Northern Governorates of Palestine. An Unpublished Thesis Submitted to the Faculty of Graduate Studies, An-Najah National University, Nablus, Palestine

xiv. Nweke, C. O., Abonyi, O. S., Omebe, C. A., \& Njoku, M. I. A. (2014).Effects of experiential teaching method on pupils' achievement in basic science and technology. International Journal of Scientific \& Engineering Research, 5(4), 875- 881.

$x v$. Omosewo, E. O. (2009). Views of physics teachers on the need to train and retrain physics teachers in Nigeria. An International Multi-Disciplinary Journal, 3(1), 313-324

xvi. Pfeifer, S., \& Borozon, D. (2011). Fitting Kolb's learning style theory to entrepreneurshiplearning aims and contents. International Journal of Business Research, 11(2), 216-223

xvii. Powell, K., \& Wells, M. (2010). The effectiveness of three experimental teaching approaches on student science learning in fifth-grade public school classrooms. The Journal of Environmental Education, 33(2), 33 - 38

xviii. Wambugu, P.W., Changeiywo, J.M., \& Ndiritu, F.G. (2014). Effects of experiential cooperative concept mapping instructional approach on secondary school students' achievement in physics in Nyeri country, Kenya. Journal of Education and Practice, 5(15), 74-83. 